Article

\title{
Variations of Growth and Toxin Yield in Cylindrospermopsis raciborskii under Different Phosphorus Concentrations
}

\author{
Yiming Yang ${ }^{1,3,+}$, Yongguang Jiang ${ }^{2,+}$, Xiaochuang $\mathrm{Li}^{1,3}, \mathrm{Hua} \mathrm{Li}^{1}$, Youxin Chen ${ }^{1,3}$, Jinlin Xie ${ }^{1,4}$, \\ Fangfang Cai ${ }^{1,3}$ and Renhui $\mathrm{Li}^{1, *}$ \\ 1 Key Laboratory of Algal Biology, Institute of Hydrobiology, Chinese Academy of Sciences, Wuhan 430072, \\ Hubei, China; yangyiming9191@163.com (Y.Y.); xiaochuangli201@gmail.com (X.L.); lih@ihb.ac.cn (H.L.); \\ chenyouxin@ihb.ac.cn (Y.C.); xiejinlin1991@sina.com (J.X.); cai15926359926@163.com (F.C.) \\ 2 Shenzhen Key Laboratory of Marine Bio-Resource and Eco-Environmental Science, Shenzhen University, \\ Shenzhen 518060, Guangdong, China; jyg1949@163.com \\ 3 University of Chinese Academy of Sciences, Beijing 100049, China \\ 4 College of Life Sciences, Jiangxi Normal University, Nanchang 330022, Jiangxi, China \\ * Correspondence: reli@ihb.ac.cn; Tel.: +86-27-6878-0067; Fax: +86-27-6878-0123 \\ + These authors contributed equally to this work.
}

Academic Editor: Greg Boyer

Received: 6 October 2016; Accepted: 24 December 2016; Published: 29 December 2016

\begin{abstract}
The bloom-forming cyanobacteria, Cylindrospermopsis raciborskii, is a producer of the cytotoxic cylindrospermopsin (CYN). In this study, the growth, toxin yield, and expression of CYN biosynthesis genes of $C$. raciborskii were examined under varying phosphorus $(\mathrm{P})$ concentrations. The results show the cell number at 0.00 and $0.01 \mathrm{mg} \cdot \mathrm{L}^{-1} \mathrm{P}$ was significantly lower than that at higher P concentrations $\left(\geq 0.5 \mathrm{mg} \cdot \mathrm{L}^{-1}\right)$. The chlorophyll $a$ content, filament length, heterocyst, and akinete numbers at $\mathrm{P} \leq 0.05 \mathrm{mg} \cdot \mathrm{L}^{-1}$ were also significantly reduced. The intracellular and extracellular CYN concentrations and the extracellular proportions increased during the culture period, and larger values were observed at higher P concentrations. Total CYN content reached 45.34-63.83 fg. cell ${ }^{-1}$ and extracellular CYN proportion reached $11.49 \%-20.44 \%$ at the stationary growth phase. A significantly positive correlation was observed between CYN production and cell growth rate. Three cyr genes were expressed constantly even at P-deficient conditions. The transcription of cyr genes at P-replete conditions or after $\mathrm{P}$ supplementation increased from 1.18-fold to 8.33 -fold. In conclusion, C. raciborskii may rapidly reorganize metabolic processes as an adaptive response to environmental $\mathrm{P}$ fluctuations. CYN production and cyr gene expression were constitutive metabolic processes in toxic $C$. raciborskii.
\end{abstract}

Keywords: Cylindrospermopsis raciborskii; cylindrospermopsin; cyr gene; inorganic phosphorus; growth rate

\section{Introduction}

Increased incidence of harmful cyanobacterial blooms were amongst the most severe environmental problems over the past two decades. Cyanobacterial blooms have attracted considerable scientific attention because of their potential risks related to human sickness and animal mortality and the disruption of aquatic ecosystems [1,2]. Toxic metabolites of cyanobacteria, i.e., cyanotoxins, can be classified into four major categories based on their mode of action. Among these compounds are the hepatotoxic microcystins [3] and nodularins [4]; the cytotoxic cylindrospermopsins (CYNs) [5]; the neurotoxic saxitoxins [6], anatoxin- $a$ [7], and beta-methylamino-L-alanine [8]; and the dermatotoxic Lyngbya toxins [9] and aplysiatoxins [10]. Specifically, the alkaloid CYN, which is composed of a tricyclic guanidine moiety coupled with a hydroxymethyluracil and a sulfonic acid group, is of particular 
concern because of the human poisoning event on Palm Island in 1979 [5,11,12]. High concentrations of CYN in water bodies may have been caused by high chemical stability and low degradation efficiency [13]. In addition, CYN can interfere with multiple cellular metabolic processes [14,15] and cause injury in several organs, including the liver, thymus, kidney, and heart [16]. Four natural congeners of CYN have been described, namely, 7-epi-CYN (a C-7 epimer) [17], 7-deoxy-CYN (no hydroxylation on C-7) [18], 7-deoxy-desulfo-CYN and 7-deoxy-desulfo-12-acetyl-CYN [19]. The biosynthesis pathway of CYN has also been proposed based on the deduced function of each CYN gene (cyr) [20].

Cylindrospermopsis raciborskii, a filamentous diazotrophic cyanobacterial species, belongs to the order Nostocales. As the first recognized CYN producer, C. raciborskii has become one of the most well-known bloom-forming cyanobacteria [21,22]. It is emerging in phytoplankton communities worldwide, displaying invasive behaviour as its occurrence spreads from tropical [23] and subtropical $[24,25]$ to temperate climate zones $[1,26]$. This species is widespread in many regions of the world including Asia, Australia, New Zealand, Europe, Africa, South and North America [27]. However, CYN producers of C. raciborskii have so far been reported only in Asian, Australia, and New Zealand water bodies [27]. Several explanations for this phenomenon have been suggested and multiple factors associated with C. raciborskii have been proposed [28], including high phenotypic plasticity, wide range of tolerance to key environmental factors [29], superior competition for resources [30], global warming [31], and eutrophication [32]. The relationships among cyanobacterial blooms, nutrient levels, and response of cyanobacteria to changes in nutritional conditions have always been active research topics. Cyanobacteria are frequently subjected to nutrient deficiency, particularly nitrogen, phosphorus $(\mathrm{P})$, and sulfur in natural water bodies [33], which probably affects the physiology and metabolism of these organisms as a consequence. As one of the most essential nutrients, $P$ plays a crucial role in determining primary productivity of water body [34]. Trimbee and Prepas [35] suggested the total P (TP) as a good indicator of the relative biomass of blue-green algae. An alteration in P loading may give rise to a shift in the phytoplankton species composition [36]. Long-term (1991-2013) data in Lake Dianchi showed that variation in the TP concentration had significant effects on the phytoplankton biomass both interannually and seasonally [37]. Chen et al. [38] inferred that the recession of cyanobacterial blooms could arise from the decrease in dissolved phosphorus. As a portion of TP, dissolved P comprised of dissolved inorganic phosphate (DIP) and dissolved organic phosphorus (DOP), can be absorbed and utilized by phytoplankton immediately [39]. DIP is directly bioavailable and is considered the preferred P source for phytoplankton [40] $\mathrm{m}$ while DOP can also be exploited [41].

Nitrogen is also considered an important nutrient for controlling cyanobacteria growth. However, efforts to reduce nitrogen levels in lakes and reservoirs were accompanied with the increase in the frequency and abundance of Nostocales [42,43]. Most of the reported CYN producers belong to the Nostocales, which can fix atmospheric nitrogen and, thus, compensate for nitrogen limitation [42,43]. Under these circumstances, inorganic $\mathrm{P}$ is, therefore, one of the primary restriction factors influencing the growth of CYN-producing species [44]. In a previous study, Bar-Yosef et al. [45] proposed CYN as an allelopathic compound that can induce alkaline phosphatase activity of surrounding phytoplankton to supply inorganic P for Chrysosporum ovalisporum (basionym: Aphanizomenon ovalisporum). To understand this phenomenon, the distribution of CYN within cyanobacterial cells and freshwater bodies must be clarified first.

Previous studies showed that CYN is highly water-soluble because of its sulfonic acid group and can be largely released into the extracellular environment [46,47]. In German lakes, the cyanobacterial community were mainly composed of Aphanizomenon, Anabaena, Anabaenopsis, Raphidiopsis, Cylindrospermopsis and Planktothrix, and more than $80 \%$ of total CYN was detected extracellularly among $31 \%$ of the samples [47]. Jiang et al. [48] observed high extracellular percentages of CYN (92\%-96\%) in C. raciborskii AWT 205. In another study with this cyanobacterium, the percentage of extracellular CYN increased from $20 \%$ during the rapid growth phase to $50 \%$ during the slow growth phase [49]. However, Saker and Griffiths [50] found up to $90 \%$ of CYN remained within the cell during 
exponential growth in seven cultured strains of C. raciborskii. In addition, Bormans et al. [51] observed no relationship between CYN concentration and growth rate in benthic species Oscillatoria sp. PCC 6506 and the percentage of extracellular CYN varied between $56 \%$ and $96 \%$. Moreover, several studies have inferred that the release of CYN increases as cells age, based on observations that the highest dissolved CYN content was found in older blooms [46] or during stationary phase of batch cultures [49,52]. Consistent with these reports, Davis et al. [53] regarded CYN release into the water column as a result of cell lysis during the stationary phase or environmental stress.

Given the critical importance of $\mathrm{P}$ availability in growth and blooms development of cyanobacteria, we investigated the growth and toxin yield of a toxic $C$. raciborskii strain under a range of inorganic $P$ concentrations. This study measured the changes in morphology, toxin yield and the expression of cyr genes in C. raciborskii. The key genes chosen were involved in CYN biosynthesis and transport, such as cyrA (amidinotransferase, the first step in CYN biosynthesis), cyrJ (sulfotransferase), and cyrK (putative transport).

\section{Results}

\subsection{Effects of P Concentration on the Growth and Morphology of C. raciborskii}

During eight days of $\mathrm{P}$ starvation, cell growth rates of $\mathrm{P}$ starvation treatment and control group were $0.15 \pm 0.03 \mathrm{day}^{-1}$ and $0.17 \pm 0.02 \mathrm{day}^{-1}$, respectively, with no significant difference $(p>0.05)$. Moreover, reduced chlorophyll $a$ contents and filament lengths and inhibition of heterocyst and akinete formation were observed (Figure 1B,C,E,F). However, in the subsequent culture period, the cell growth rate, chlorophyll $a$ content, and morphological parameters were all reduced even after $\mathrm{P}$ was supplied at the eighth day, compared with the control group with excess P concentration. Furthermore, the $\mathrm{OD}_{750}$ values and the cell number at 0.00 and $0.01 \mathrm{mg} \cdot \mathrm{L}^{-1} \mathrm{P}$ were significantly lower than those at higher $\mathrm{P}$ concentrations $(p<0.05$; Figure $1 \mathrm{~A}, \mathrm{D})$. The maximum $\mathrm{OD}_{750}$ values were $0.40 \pm 0.01$, $0.45 \pm 0.01,0.51 \pm 0.01$, and $0.55 \pm 0.03$ for $0.00,0.01,0.05$, and $0.50 \mathrm{mg} \cdot \mathrm{L}^{-1} \mathrm{P}$, respectively (Figure $1 \mathrm{~A}$ ). The maximum cell numbers were $8.53 \times 10^{6} \pm 4.37 \times 10^{5}, 9.13 \times 10^{6} \pm 1.86 \times 10^{5}, 1.05 \times 10^{7} \pm$ $9.36 \times 10^{5}$, and $1.08 \times 10^{7} \pm 1.37 \times 10^{6}$ cells $\cdot \mathrm{mL}^{-1}$ for $0.00,0.01,0.05$, and $0.50 \mathrm{mg} \cdot \mathrm{L}^{-1} \mathrm{P}$, respectively (Figure 1D). The maximum $\mathrm{OD}_{750}$ value and cell number in the control group were $0.57 \pm 0.01$ and $1.05 \times 10^{7} \pm 1.05 \times 10^{6}$ cells $\cdot \mathrm{mL}^{-1}$, respectively. 

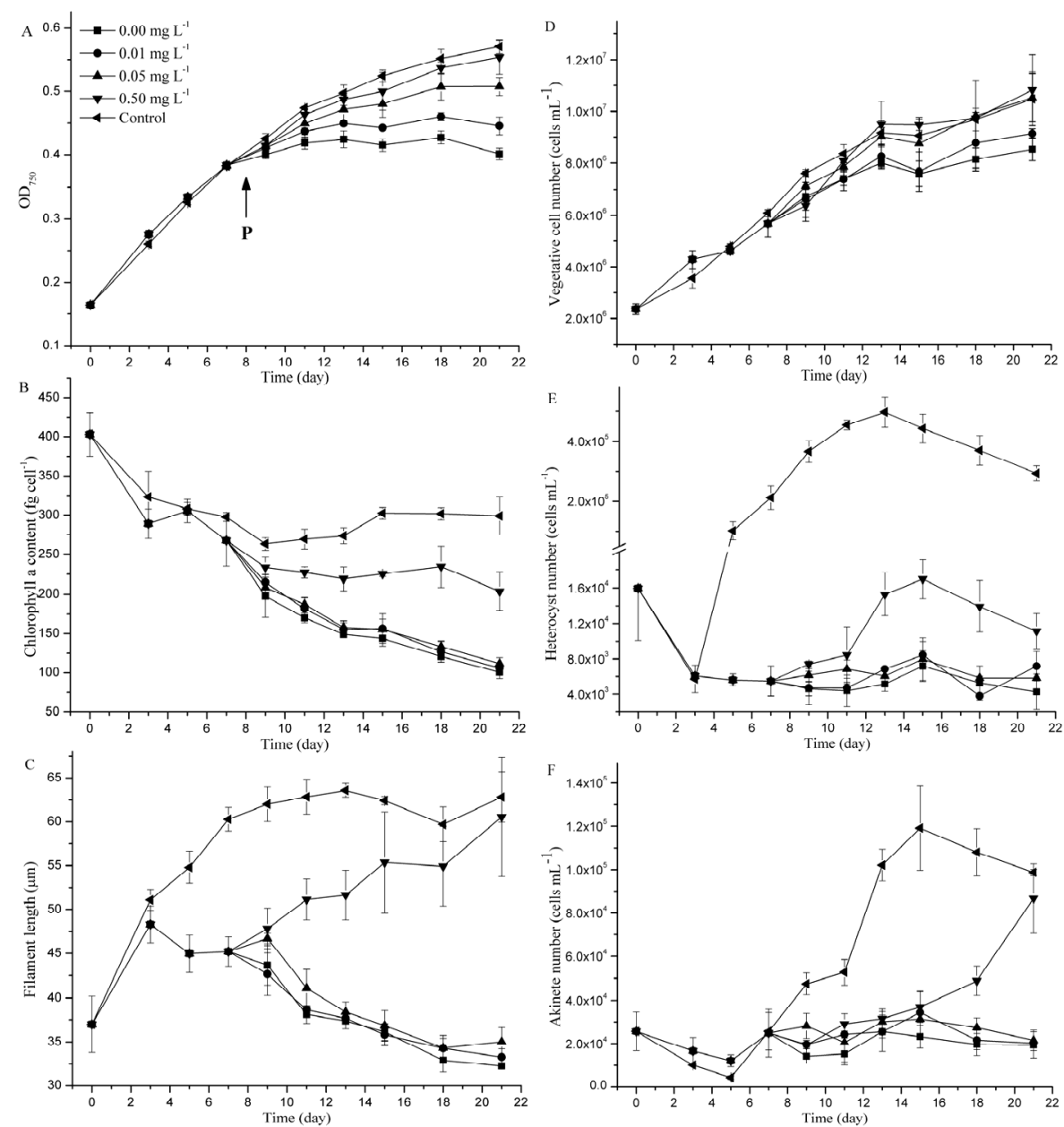

Figure 1. Growth and morphology of $C$. raciborskii incubated with different $P$ concentrations. (A) $\mathrm{OD}_{750}$ value; (B) chlorophyll $a$ content; (C) filament length; and (D-F), the number of total cells, heterocysts and akinetes. Error bars represent standard deviations. The vertical arrow shows the time when phosphate was supplemented.

The chlorophyll $a$ content (after the 10th day), filament length (after the 10th day), and heterocyst (after the 12th day) and akinete (after the 17 th day) numbers at $0.00,0.01$, and $0.05 \mathrm{mg} \cdot \mathrm{L}^{-1} \mathrm{P}$ were significantly lower than those at $0.50 \mathrm{mg} \cdot \mathrm{L}^{-1} \mathrm{P}$ and in the control group $(p<0.05$; Figure 1B,C,E,F). The chlorophyll $a$ contents at $0.00,0.01$, and $0.05 \mathrm{mg} \cdot \mathrm{L}^{-1} \mathrm{P}$ were decreased from $402.89 \pm 27.70 \mathrm{fg} \cdot \mathrm{cell}^{-1}$ to $100.51 \pm 7.45,106.19 \pm 3.45$, and $111.86 \pm 7.46 \mathrm{fg} \cdot$ cell $^{-1}$, respectively, for each group, compared with the final chlorophyll $a$ contents of $203.66 \pm 23.99$ and $298.95 \pm 24.46 \mathrm{fg} \cdot \mathrm{cell}^{-1}$ for $0.50 \mathrm{mg} \cdot \mathrm{L}^{-1} \mathrm{P}$ and the control group, respectively (Figure 1B). Similarly, the filament lengths were decreased from $36.99 \pm 3.20 \mu \mathrm{m}$ to $32.23 \pm 0.06,33.26 \pm 0.94$, and $35.02 \pm 1.63 \mu \mathrm{m}$ for $0.00,0.01$, and $0.05 \mathrm{mg} \cdot \mathrm{L}^{-1} \mathrm{P}$, respectively, whereas the filament lengths for $0.50 \mathrm{mg} \cdot \mathrm{L}^{-1} \mathrm{P}$ and the control group were greater at $60.56 \pm 6.82$ and $62.81 \pm 2.88 \mu \mathrm{m}$, respectively, at the end of the experimental stationary phase (Figure 1C). The maximum numbers of heterocysts were $7.18 \times 10^{3} \pm 1.73 \times 10^{3}, 8.42 \times 10^{3} \pm$ $1.54 \times 10^{3}, 7.97 \times 10^{3} \pm 2.39 \times 10^{3}$, and $1.70 \times 10^{4} \pm 2.17 \times 10^{3}$ heterocysts $\mathrm{mL}^{-1}$ for $0.00,0.01,0.05$, and $0.50 \mathrm{mg} \cdot \mathrm{L}^{-1} \mathrm{P}$, respectively (Figure $1 \mathrm{E}$ ). The maximum numbers of akinetes were $2.56 \times 10^{4} \pm 9.23$ $\times 10^{3}, 3.43 \times 10^{4} \pm 9.95 \times 10^{3}, 3.13 \times 10^{4} \pm 3.36 \times 10^{2}$, and $8.67 \times 10^{4} \pm 1.60 \times 10^{4}$ akinetes $\mathrm{mL}^{-1}$ for $0.00,0.01,0.05$, and $0.50 \mathrm{mg} \cdot \mathrm{L}^{-1} \mathrm{P}$, respectively (Figure $1 \mathrm{~F}$ ). The maximum heterocyst and akinete numbers in the control group were $4.97 \times 10^{5} \pm 5.04 \times 10^{4}$ heterocysts $\mathrm{mL}^{-1}$ and $1.19 \times 10^{5} \pm$ $1.95 \times 10^{4}$ akinetes $\mathrm{mL}^{-1}$, respectively. 


\subsection{CYN Measurement}

CYN contents in the C. raciborskii culture were measured and normalized to the total cell numbers (Figure 2). The cell quotas of intracellular, extracellular, and total CYN gradually increased under all treatments over the experimental period. The total CYN cell quota was calculated as the sum of intracellular and extracellular CYN cell quota. Moreover, the groups with higher P concentrations had larger $\mathrm{CYN}$ amounts than the groups with lower $\mathrm{P}$ concentrations at most time points. Intracellular CYN accounted for the majority of total CYN with $38.72 \pm 1.12,39.21 \pm 1.61,44.71 \pm 4.08,45.06 \pm 5.78$, and $50.79 \pm 2.13 \mathrm{fg} \cdot \mathrm{cell}^{-1}$ for P concentrations of $0.00,0.01,0.05$, and $0.50 \mathrm{mg} \cdot \mathrm{L}^{-1}$ and the control group, respectively (Figure 2). A minor portion of CYN was extracellular with $6.75 \pm 0.32,6.13 \pm$ $0.66,5.80 \pm 1.00$ and $7.61 \pm 1.16 \mathrm{fg} \cdot$ cell $^{-1}$ for cells grown in P concentrations of $0.00,0.01,0.05$, and $0.50 \mathrm{mg} \cdot \mathrm{L}^{-1}$, which were significantly lower than $13.04 \pm 0.14 \mathrm{fg} \cdot$ cell $^{-1}$ in the control group $(p<0.01$; Figure 2). The final total CYN contents reached $45.47 \pm 1.43,45.34 \pm 2.23,50.51 \pm 4.43,52.67 \pm 6.59$, and $63.83 \pm 2.09 \mathrm{fg} \cdot$ cell $^{-1}$ for P concentrations of $0.00,0.01,0.05$, and $0.50 \mathrm{mg} \cdot \mathrm{L}^{-1}$ and the control group, respectively (Figure 2). With regard to intracellular CYN and total CYN, no significant differences were found among cells grown with $\mathrm{P} \leq 0.05 \mathrm{mg} \cdot \mathrm{L}^{-1}(p>0.05)$, while the values of cells grown with $\mathrm{P}>0.05 \mathrm{mg} \cdot \mathrm{L}^{-1}$ were significantly higher than that of those under $\mathrm{P}$ depletion condition $(p<0.01)$.
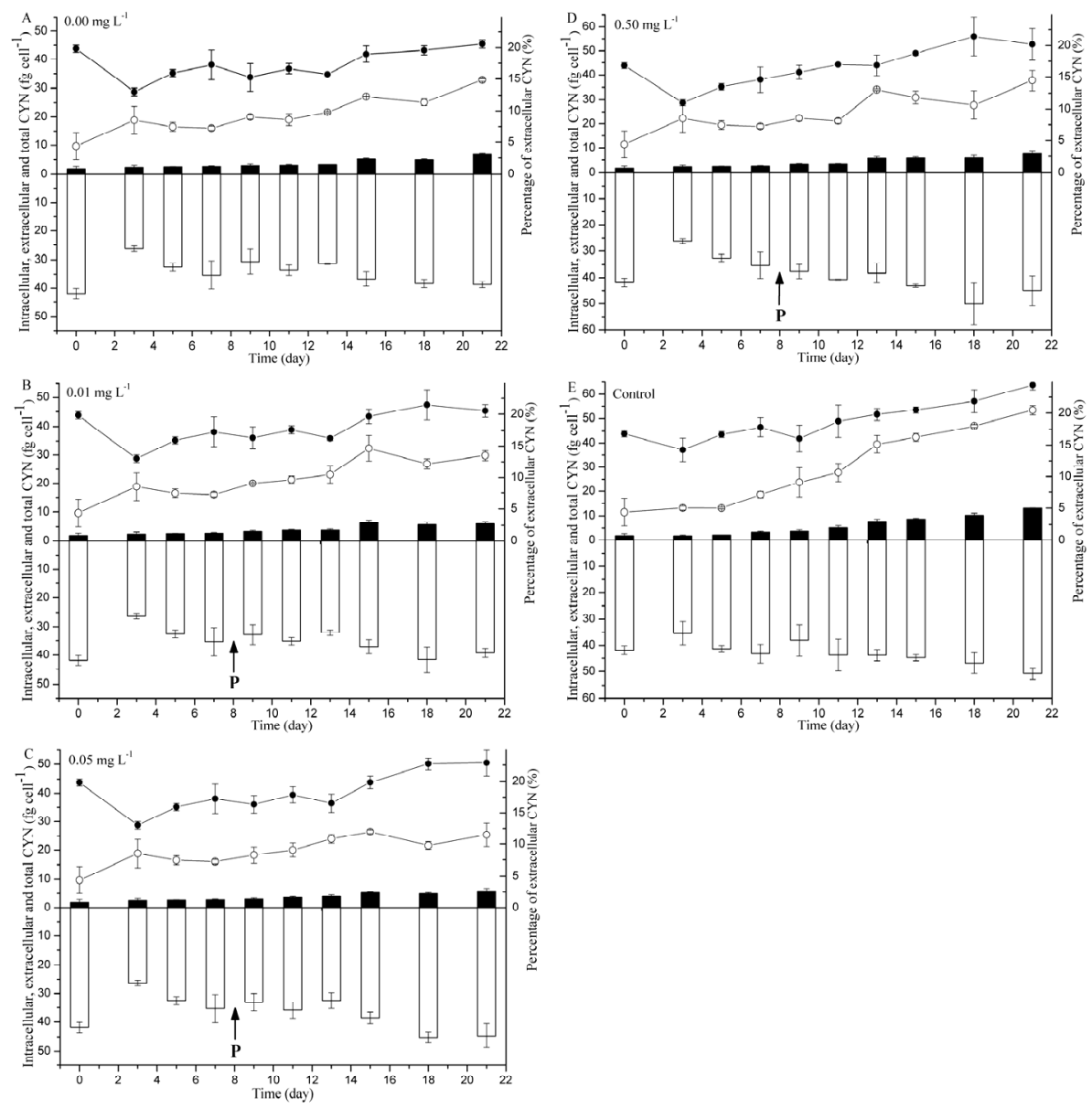

Figure 2. CYN content in C. raciborskii culture with P concentrations of $(\mathbf{A}) 0.00 \mathrm{mg} \cdot \mathrm{L}^{-1},\left(\right.$ B) $0.01 \mathrm{mg} \cdot \mathrm{L}^{-1}$, (C) $0.05 \mathrm{mg} \cdot \mathrm{L}^{-1}$, (D) $0.50 \mathrm{mg} \cdot \mathrm{L}^{-1}$ and (E) Control. The pool size of intracellular ( $\square$ ), extracellular (घ), and total CYN $(\bullet)$, as well as the percentage of extracellular CYN $(\bigcirc)$ were displayed. Error bars represent standard deviations. The vertical arrows show the time when phosphate was supplemented.

The percentage of extracellular CYN also increased during the sampling period. At the last day of the experiment, a significantly higher CYN percentage was observed to be extracellular in the control 
group $(20.44 \% \pm 0.75 \%)$, compared with extracellular percentages of $14.83 \% \pm 0.23 \%, 13.50 \% \pm 0.81 \%$, $11.49 \% \pm 1.86 \%$, and $14.45 \% \pm 1.60 \%$ at $\mathrm{P}$ concentrations of $0.00,0.01,0.05$, and $0.50 \mathrm{mg} \cdot \mathrm{L}^{-1}$, respectively $(p<0.01$; Figure 2$)$. Furthermore, both $\mu_{C Y N \text {-total }}$ and $\mu_{C Y N-i n}$ showed a significantly positive correlation with $\mu_{c}(p<0.05$; Figure 3$)$. The slope were 0.96 and 0.95 , respectively, both of which were not significantly different from 1.00 (ANCOVA: $p=0.83$ for $\mu_{C Y N \text {-total }}$ and $p=0.80$ for $\mu_{C Y N-i n}$ ).
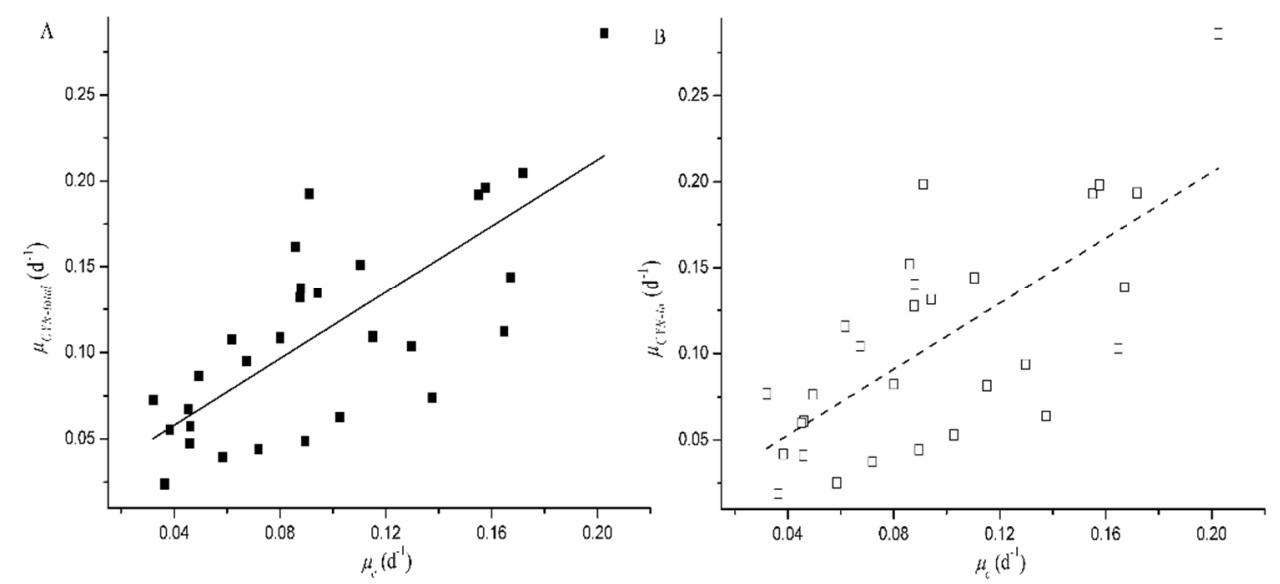

Figure 3. Correlations between specific toxin production rate $\left(\mu_{\mathrm{CYN}}\right)$ and the corresponding specific growth rate $\left(\mu_{c}\right)$ during culture period. (A) $\mu_{C Y N \text {-total }}$ represents specific total toxin production rate and (B) $\mu_{C Y N-i n}$ represents specific intracellular toxin production rate. The linear regression equations are as follows: (A) $y=0.96 x+0.02, R^{2}=0.54, p=0.00$; and (B) $y=0.95 x+0.01, R^{2}=0.48, p=0.00$.

\section{3. cyr Gene Expression}

The expression levels of three cyr genes, namely, cyrA, cyrJ, and cyrK, were examined, and their transcript abundances were expressed as the fold changes with respect to time $=0$. In the P starvation stage, upregulated expression levels of $c y r A$ and $c y r K$ genes were observed for the control and experimental groups compared with the initial expression levels (Figure 4A,C). The expression of $c y r J$ gene was also increased in the early stage of $P$ starvation and was reduced to initial levels subsequently (Figure 4B). Furthermore, the expression levels of cyrA gene in the P-depleted group were $12 \%, 26 \%$, and $72 \%$ of those in the control group after $0.5,1$, and 7 days, respectively, with significant difference $(p<0.05)$. The expression levels of cyrJ gene in the P-depleted group were $25 \%, 36 \%$, and $77 \%$ of those in the control group after $0.5,1$, and 2 days, respectively, with significant difference $(p<0.05)$. The expression levels of cyrK gene in the P-depleted group were $20 \%, 57 \%$, and $85 \%$ of those in the control group after $0.5,1$, and 5 days, respectively, with significant difference $(p<0.05)$. However, a significant 1.74-fold increase in cyrK gene expression was observed in the P-depleted group after seven days compared with the control group. Moreover, no significant difference was observed for the expression levels of $c y r$ genes between P-depleted and control groups at the last day of $\mathrm{P}$ starvation $(p>0.05)$. 

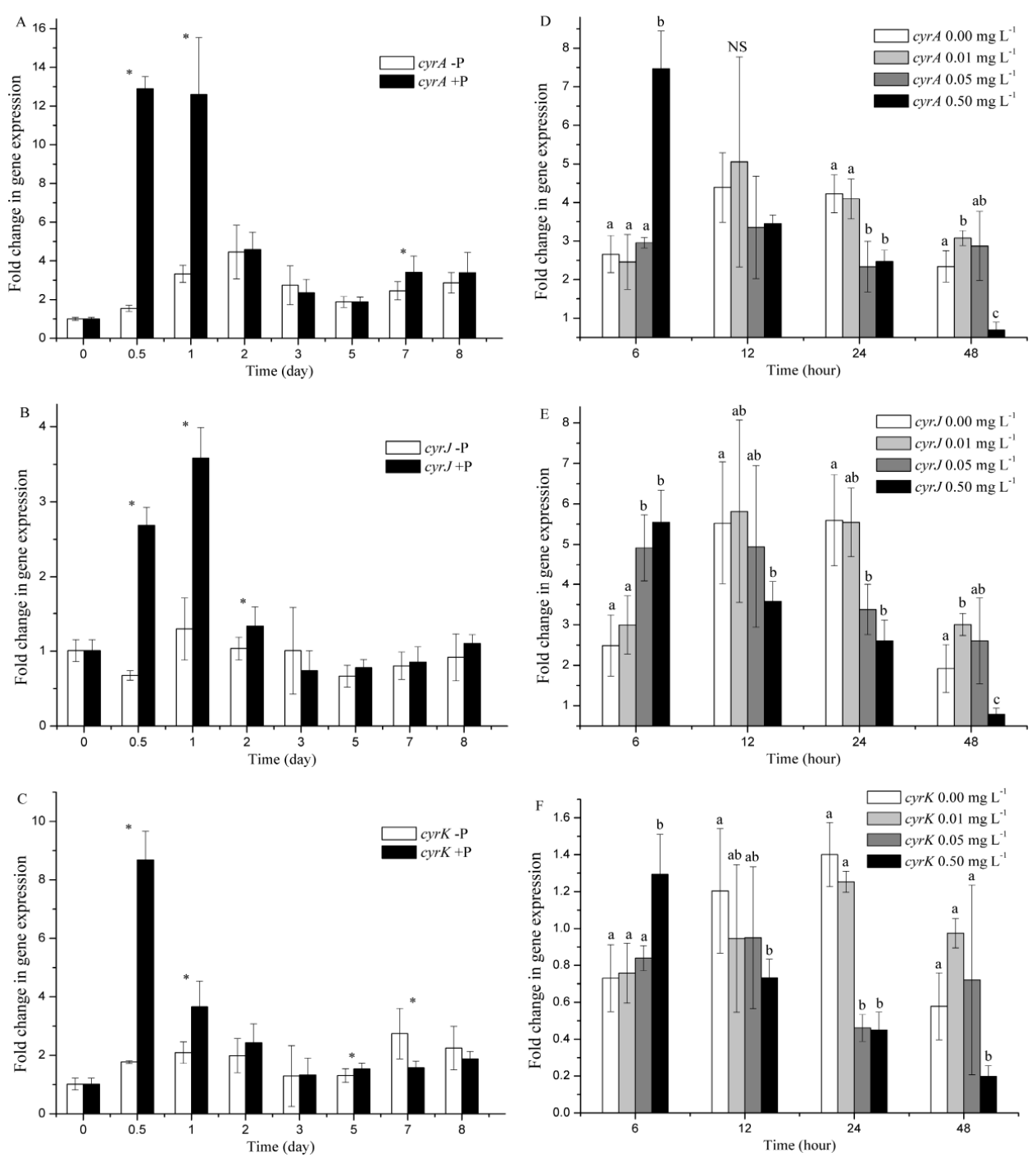

Figure 4. Relative expression levels of cyr genes under $\mathrm{P}$ starvation $(\mathbf{A}-\mathbf{C})$ and varying $\mathrm{P}$ concentrations (D-F). Fold changes in gene expression were calculated by dividing the values at time $=0$. The time in $\mathbf{D}, \mathbf{E}$, and $\mathbf{F}$ was counted after the supplement of P. Error bars represent standard deviations. Asterisk and different letters represent significant differences among groups $(p<0.05)$ at a single time point.

After P supplementation on the eighth day, the expression levels of $c y r A$ and $c y r K$ genes were significantly increased to 2.81 -fold and 1.77 -fold, respectively, at $0.50 \mathrm{mg} \cdot \mathrm{L}^{-1} \mathrm{P}$ compared with those in the P-depleted group after $6 \mathrm{~h}(p<0.05$; Figure 4D,F). Similarly, the expression levels of cyrJ gene at 0.05 and $0.50 \mathrm{mg} \cdot \mathrm{L}^{-1} \mathrm{P}$ were 1.97-fold and 2.23-fold higher, respectively, than those in the P-depleted group after $6 \mathrm{~h}$, with significant difference ( $p<0.05$; Figure $4 \mathrm{E})$. Afterward, the cyr gene expression levels at $0.05 \mathrm{mg} \cdot \mathrm{L}^{-1} \mathrm{P}$ were reduced and were $55 \%, 60 \%$, and $33 \%$ of those in the P-depleted groups for the cyr $A$, cyrJ, and cyrK genes, respectively, after $24 \mathrm{~h}$, with significant difference $(p<0.05)$. The cyr gene expression levels at $0.50 \mathrm{mg} \cdot \mathrm{L}^{-1} \mathrm{P}$ were also reduced and were $30 \%-79 \%, 41 \%-65 \%$, and $32 \%-61 \%$ of those in the P-depleted group for the cyrA, cyrJ, and cyrK genes, respectively, with significant difference, except after $12 \mathrm{~h}$. The cyr gene expression levels at $0.01 \mathrm{mg} \cdot \mathrm{L}^{-1} \mathrm{P}$ were not significantly different from that in the P-depleted group at most time points, except for significantly higher expression levels of the cyr $A$ and cyrJ genes at $0.01 \mathrm{mg} \cdot \mathrm{L}^{-1} \mathrm{P}$ after $48 \mathrm{~h}$. 


\subsection{Correlation between the Biomass of Cylindrospermopsis and TP Concentration in Freshwater Bodies}

Among a series of phytoplankton species and water quality parameters, we centered on Cylindrospermopsis and TP concentration. The percentage of Cylindrospermopsis in total cyanobacterial biomass showed the tendency of negative correlation with TP concentration $(y=-1.68 x+6.44$, $\left.R^{2}=0.50, p=0.00\right)$, compared with the positive correlation between the percentage of Microcystis and TP concentration $\left(y=0.60 x+0.58, R^{2}=0.08, p=0.03\right)$ (Figure 5).

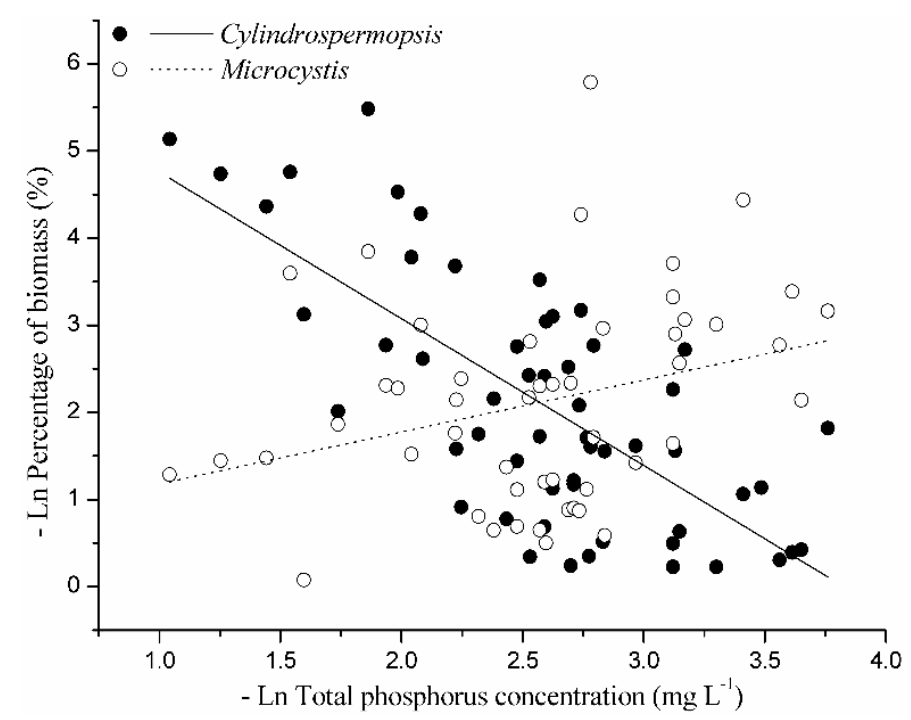

Figure 5. Correlations between percentage of cyanobacterial biomass and TP concentrations in freshwater bodies. Cylindrospermopsis, $y=-1.68 x+6.44, R^{2}=0.50, p=0.00 ;$ Microcystis, $y=0.60 x+0.58$, $R^{2}=0.08, p=0.03$.

\section{Discussion}

In this study, we explored the P-dependent growth, toxin yield, and the expression levels of the cyr genes cyr A, cyrJ, and cyrK, in C. raciborskii CHAB3438. This strain could grow at very low $\mathrm{P}$ concentrations during the experimental period, and this corresponds with the high $\mathrm{P}$ affinity and large P storage that has been previously reported for C. raciborskii [54-56]. However, the chlorophyll $a$ content per cell was lower at the lower P concentrations compared to the higher P concentrations. Additionally, filament length and formation of heterocysts and akinetes were also reduced at low P concentrations. The explanation for this physiological response is that C. raciborskii is able to economize resources by adjusting metabolic pathways and reducing high energy-consuming physiological processes under limited nutrient supply, a response also found in Microcystis aeruginosa [57]. The phenotypic plasticity of multiple traits may allow C. raciborskii to optimize growth in P fluctuations, which may explain its dominance in the phytoplankton of many aquatic ecosystems, particularly those with low $\mathrm{P}$ concentrations [58]. Furthermore, field surveys of this study also showed a trend where the relative abundance of Cylindrospermopsis increased with the decline of TP concentration in lakes. This result is consistent with the investigation of Bonilla et al. [59] that observed a high biomass of C. raciborskii under low TP concentration. Therefore, Cylindrospermopsis is highly competitive and adaptive under low P concentrations compared with other bloom-forming cyanobacteria, which significantly promotes its invasive spread.

Previous investigations revealed that $\mathrm{P}$ deprivation inhibited CYN production in Chr. ovalisporum [60]. On the other hand, replete P supply was found to boost CYN yield in C. raciborskii and cyanobacterial blooms samples [61,62]. However, only intracellular CYN was measured in these studies, and the extracellular portion of CYN was ignored. On the contrary, an increase in the total CYN content was reported under P-depleted conditions, coupled with 
upregulated expression levels of the CYN biosynthesis genes [45,63]. Therefore, it is necessary to explore the extracellular $\mathrm{CYN}$ concentration under different $\mathrm{P}$ concentrations to clarify the contradiction of these results. In this study, the concentrations of intracellular, extracellular and total CYN, as well as the extracellular proportion of CYN, all increased during the culture time and at all $\mathrm{P}$ concentrations. The CYN production rate exhibited a positive correlation with cell growth rate, therefore, $\mathrm{CYN}$ production is constitutive in C. raciborskii CHAB3438. The effects of $\mathrm{P}$ concentrations on these processes were produced through affecting cell growth. Therefore, CYN yield would be reduced when cell maximum biomass is reduced under P-limited conditions. These results were supported by previous findings that the $C Y N$ pool size of $C$. raciborskii was constant under different nitrogen, phosphorus, light, and $\mathrm{CO}_{2}$ conditions $[64,65]$.

At the end of the experiment, the proportion of extracellular CYN reached $11.49 \%$ to $20.44 \%$ of the total CYN, indicating that CYN is mainly stored in cyanobacterial cells, whereas only a minor proportion of CYN is released into the extracellular environment, consistent with the results of Orr et al. [66] with field cyanobacterial samples. Cell lysis may contribute to extracellular CYN accumulation during the stationary phase as suggested in previous research [53]. In addition, active CYN release from cyanobacterial cells has been emphasized in other studies [63], but it remains to be proved. The hypothetical CYN transporter CyrK has been deduced from the biosynthesis cluster [20] but its function needs to be confirmed by examining a mutant strain lacking the cyrK gene.

The transcription of three cyr genes that are involved in CYN biosynthesis and transport was examined to better understand the potential response of $c y r$ gene cluster in $C$. raciborskii to various $P$ concentrations. The results showed significantly high expression levels of $c y r$ genes under P-replete conditions in the early stage of $\mathrm{P}$ starvation and in the initial $6 \mathrm{~h}$ of $\mathrm{P}$ supplementation thereafter. Afterwards, the expression levels of cyr genes at various P concentrations maintained similar levels during the experimental period; however, significantly lower expression levels were observed for 0.05 and $0.50 \mathrm{mg} \cdot \mathrm{L}^{-1} \mathrm{P}$ in comparison to other $\mathrm{P}$ concentrations at several time points. Although the cyr gene expression did not completely coincide with the production and release of CYN, which was constitutive as aforementioned, the constant expression of $c y r$ genes further confirmed $\mathrm{CYN}$ as a constitutive metabolite of the toxic C. raciborskii. In a study with C. raciborskii CS-505, Stucken et al. [67] investigated the relationship between expression levels of four cyr genes and $\mathrm{CYN}$ production in response to nitrogen source. They also found that these genes showed a constitutive transcription and concluded that CYN biosynthesis was not regulated at the transcriptomic level. Furthermore, Pierangelini et al. [64] reported differential expression of cyr genes in contrast to constant CYN cell quotas in different growth stages of $C$. raciborskii, and suggested CYN biosynthesis was post-transcriptionally regulated. Our results support the post-transcriptional regulation of CYN for a constant cell quota.

\section{Conclusions}

In summary, the morphology of $C$. raciborskii and the expression of the genes cyrA, cyrJ, and cyrK, altered in response to variations in environmental $\mathrm{P}$, however, $\mathrm{CYN}$ production and release remain constitutive processes. The majority of CYN occurred intracellularly with only a small proportion $(4.38 \%-14.83 \%)$ occurring extracellularly. Finally, the toxin yield of C. raciborskii blooms would be reduced with a reduction in available $\mathrm{P}$, as $\mathrm{P}$ limits the maximum total cell number.

\section{Materials and Methods}

\subsection{Strain and Culture Conditions}

CYN-producing strain C. raciborskii CHAB3438 was previously isolated from Lake Xianghu and maintained in liquid MA medium [68]. Quintuplicate $1 \mathrm{~L}$ pure cultures in sterile $2 \mathrm{~L}$ Erlenmeyer flasks were incubated in $25^{\circ} \mathrm{C}$ with a light intensity of $35 \mu \mathrm{mol} \mathrm{m}{ }^{-2} \cdot \mathrm{s}^{-1}(12 / 12 \mathrm{~h} \mathrm{light/dark})$ provided by cool white fluorescent tubes. The cultures were manually shaken thrice daily during incubation until the exponential phase. 


\subsection{Phosphorus Starvation and Supplementation}

The cultures were filtered using Millipore membranes $(3.0 \mu \mathrm{m}$ pore size, Merck Millipore, Darmstadt, Germany), washed thrice with sterile P-free MA medium, resuspended, and subcultured into five groups. Each group included triplicate cultures containing $50 \mathrm{~mL}$ concentrated cultures and $1150 \mathrm{~mL}$ P-free MA medium (four experimental groups) or full medium (one control group with $10 \mathrm{mg} \cdot \mathrm{L}^{-1} \mathrm{P}$ ). The starting cell concentration was $2.36 \times 10^{6} \pm 2.10 \times 10^{5}$ cells $\cdot \mathrm{mL}^{-1}$. The cultures were incubated for eight days to deplete intracellular polyphosphate stores. Afterward, the four experimental groups were supplemented with $\mathrm{K}_{2} \mathrm{HPO}_{4}$ solution to obtain the final $\mathrm{P}$ concentrations of $0.00,0.01,0.05$, and $0.50 \mathrm{mg} \cdot \mathrm{L}^{-1}$. Fresh media with corresponding P concentrations were supplemented after each sampling to maintain constant culture volumes. Samples were collected on alternate days to determine cyanobacterial growth, CYN content, and gene expression level. In the P starvation stage, three of the 12 experimental cultures were randomly selected to measure each parameter. Therefore, the data of growth and CYN are shared by four experimental groups during the first eight days of P starvation.

\subsection{Measurement of Growth}

Growth was measured spectrophotometrically at $750 \mathrm{~nm}$. Subsamples $(1 \mathrm{~mL})$ were preserved in Lugol's iodine solution for microscopic measurement (Olympus BX51, 400 $\times$ magnification, Olympus, Tokyo, Japan) of morphological features, including cell concentration, heterocyst and akinete numbers, and filament length. Cell concentration was measured as described in Pierangelini et al. [69]. Filament length measurements were performed on at least 100 trichomes. For chlorophyll $a$ measurement, $20 \mathrm{~mL}$ of cell culture was filtered through a glass fiber filter ( $47 \mathrm{~mm}$ diameter, $1.2 \mu \mathrm{m}$ pore size; Whatman GF/C) and extracted using $90 \%$ acetone solution in the dark for $24 \mathrm{~h}$ at $4{ }^{\circ} \mathrm{C}$. The extracts were centrifuged at $8000 \mathrm{rpm}$ for $30 \mathrm{~min}$, and the absorbance of the supernatant was measured at 750, 663, 645 , and $630 \mathrm{~nm}$. The concentration of chlorophyll $a$ was calculated using the formula applied by the China Environmental Protection Administration [70].

\subsection{Extraction and Quantitation of $C Y N$}

A cell culture volume of $25-50 \mathrm{~mL}$ was filtered by Millipore filters $(0.22 \mu \mathrm{m}$ pore size). Intracellular and extracellular CYN were extracted from filters and filtrates, respectively. The collected cells on the filters were resuspended in $1 \mathrm{~mL}$ distilled water, fractured by a SPEX 6870 Freezer Mill for $10 \mathrm{~min}$, shaken for $1 \mathrm{~h}$ at room temperature, and centrifuged at 12,000 rpm for $30 \mathrm{~min}$. The supernatants were collected and combined after the extraction step was repeated. The supernatants and filtrates were subjected to solid-phase extraction to enrich CYN, as described previously [71]. Afterward, the elutes were further concentrated by rotary evaporation. The precipitate was redissolved in $0.5 \mathrm{~mL}$ of Millipore water and filtered through an ultra-centrifugal filter $(10 \mathrm{kDa})$. CYN was detected by high-performance liquid chromatography, and the column and elution conditions were set as descried by Jiang et al. [48]. Standard CYN (Enzo Life Sciences, New York, NY, USA) was used for qualitative and quantitative analyses. CYN concentrations in the samples were calculated based on UV absorbance at $262 \mathrm{~nm}$. The specific growth rate $\left(\mu_{c}\right)$ and specific toxin production rate $\left(\mu_{C Y N}\right)$ were calculated using the equation:

$$
\mu=\frac{\ln C_{2}-\ln C_{1}}{t_{2}-t_{1}}
$$

where $C_{1}$ and $C_{2}$ are the cell number (cells. $\mathrm{mL}^{-1}$ ) and CYN concentration $\left(\mu \mathrm{g} \cdot \mathrm{CYN} \cdot \mathrm{L}^{-1}\right)$ at times $t_{1}$ and $t_{2}$, respectively [64]. Data of days 3-21 were used to calculate $\mu_{c}$ and $\mu_{C Y N}$. The slope of regression curves were statistically analyzed, as described previously [67]. 


\subsection{RNA Isolation and cDNA Synthesis}

Cells were collected via centrifugation of $9.0-40 \mathrm{~mL}$ of culture at $8000 \mathrm{rpm}, 4{ }^{\circ} \mathrm{C}$ for $2 \mathrm{~min}$, and total RNA was extracted using the RNAiso Plus Kit (Takara, Otsu, Japan) according to the manufacturer's instructions. DNA digestion was performed after RNA isolation with RNase-free DNase (Promega, Madison, WI, USA) and RNase Inhibitor (Thermo, Waltham, MA, USA). RNA quality and purity was assessed using a Nanodrop spectrophotometer (Thermo, Waltham, MA, USA) and a total of $900 \mathrm{ng}$ of RNA was taken for reverse transcription (RT) reaction using the PrimeScript ${ }^{\text {TM }}$ RT reagent Kit with gDNA Eraser (Takara, Otsu, Japan) according to the manufacturer's instructions. Genomic DNA was further removed with gDNA Eraser during this process. The absence of genomic DNA in the RNA samples was then verified by a RT-PCR control containing no reverse transcriptase.

\subsection{Quantitative PCR (qPCR) Assay}

A three-step qPCR programme was performed in an iCycler iQ5 (Bio-Rad, Hercules, CA, USA). The procedure consisted of $95^{\circ} \mathrm{C}$ for $1 \mathrm{~min}$, followed by 40 cycles of $95^{\circ} \mathrm{C}$ for $15 \mathrm{~s}, 55^{\circ} \mathrm{C}$ for $15 \mathrm{~s}, 7{ }^{\circ} \mathrm{C}$ for $45 \mathrm{~s}$ and then a melt-curve cycle of $0.5^{\circ} \mathrm{C}$ increases at $15 \mathrm{~s}$ intervals to verify the quality of the product. All reactions were run in triplicate, which comprised $10 \mu \mathrm{L} 2 \times$ THUNDERBIRD SYBR qPCR Mix (Toyobo, Osaka, Japan), $0.2 \mu \mathrm{M}$ forward and reverse primers, $2 \mu \mathrm{L}$ cDNA and sterile Millipore water to a final reaction volume of $20 \mu \mathrm{L}$. Sanger sequencing was performed on the amplicons to confirm the presence of $c y r$ gene fragments. The qPCR primers were designed according to cyr gene sequences of C. raciborskii CHAB3438 (GenBank accession number: KJ139743). Standard curve of each primer pair was established by 10 -fold dilutions of a PCR template. The qPCR primer sequences, amplicon sizes and amplification efficiencies are shown in Table 1 . The time $=0$ point sample was used as a calibrator and $16 \mathrm{~S}$ rDNA was chosen as a reference gene for calculating fold changes of cyr $A$, cyrJ and $c y r K$ genes using the $2^{-\Delta \Delta C t}$ method, where

$$
\Delta \Delta C_{t}=\left(C_{t} \text {, target gene }-C_{t, 16 \mathrm{~S} r r n}\right)_{t}-\left(C_{t, \text { target gene }}-C_{t}, 16 \mathrm{~S} r r n\right)_{t=0} .
$$

Table 1. Characteristics of primer pairs used in RT-qPCR reactions.

\begin{tabular}{|c|c|c|c|c|}
\hline Gene & Primer & Sequence $\left(5^{\prime}-3^{\prime}\right)$ & Product Size (bp) & Efficiency (\%) \\
\hline cyrA & $\begin{array}{l}\text { qcyrAF193 } \\
\text { qcyrAR328 }\end{array}$ & $\begin{array}{c}\text { GAGGAGTTGAATGGGCTGGTA } \\
\text { GTGGGCAGACCGCACAATA }\end{array}$ & 136 & 98.94 \\
\hline cyrJ & $\begin{array}{l}\text { qcyrJF375 } \\
\text { qcyrJR507 }\end{array}$ & $\begin{array}{l}\text { TCTGATTCGCCAACCCAAAG } \\
\text { CGGGATTACTCCGCTCGTT }\end{array}$ & 133 & 98.63 \\
\hline cyrK & $\begin{array}{l}\text { qcyrKF345 } \\
\text { qcyrKR450 }\end{array}$ & $\begin{array}{l}\text { CGGGAAATAGCCAACACG } \\
\text { AAAGGGAAAGGAGCCACA }\end{array}$ & 106 & 102.02 \\
\hline $16 \mathrm{~S}$ rDNA & $\begin{array}{l}\text { q16SF1029 } \\
\text { q16SR1210 }\end{array}$ & $\begin{array}{l}\text { GTGTCGTGAGATGTTGGGTT } \\
\text { CCTCTGTCCGTAGCATTGTAG }\end{array}$ & 182 & 101.17 \\
\hline
\end{tabular}

\subsection{Collection of Water Samples}

A total of 55 sampling sites belonging to 23 shallow lakes were covered in this study. These water bodies were located in the east of China and water samples were collected in the summer of 2013 (Table S1). Analysis of water quality parameters and phytoplankton species composition were conducted as previously described [72].

\subsection{Statistical Analysis}

Data are presented as the mean \pm standard deviation. Statistical difference was tested by one-way ANOVA and Tukey's post hoc comparison test implemented in SPSS v19.0 software (IBM, Chicago, IL, USA) for Windows. Differences with $p$ values less than 0.05 were considered significant. 
Supplementary Materials: The following are available online at www.mdpi.com/2072-6651/9/1/13/s1, Table S1: Details of field samples.

Acknowledgments: This research was funded by the National Natural Science Foundation of China (31170189) and China Postdoctoral Science Foundation (2015M572349).

Author Contributions: Yiming Yang, Yongguang Jiang and Hua Li conceived and designed the experiments; Yiming Yang performed the experiments; Yiming Yang and Yongguang Jiang analyzed the data; Xiaochuang Li, Youxin Chen, Jinlin Xie and Fangfang Cai contributed reagents/materials/analysis tools; Yiming Yang and Yongguang Jiang wrote the manuscript. Hua Li and Renhui Li edited the manuscript. All authors have read and approved the final manuscript.

Conflicts of Interest: The authors declare no conflict of interest.

\section{References}

1. Sinha, R.; Pearson, L.A.; Davis, T.W.; Burford, M.A.; Orr, P.T.; Neilan, B.A. Increased incidence of Cylindrospermopsis raciborskii in temperate zones-Is climate change responsible? Water Res. 2012, 46, 1408-1419. [CrossRef] [PubMed]

2. Paerl, H.W.; Otten, T.G. Harmful cyanobacterial blooms: Causes, consequences, and controls. Microb. Ecol. 2013, 65, 995-1010. [CrossRef] [PubMed]

3. Zurawell, R.W.; Chen, H.; Burke, J.M.; Prepas, E.E. Hepatotoxic cyanobacteria: A review of the biological importance of microcystins in freshwater environments. J. Toxicol. Environ. Health B 2005, 8, 1-37. [CrossRef] [PubMed]

4. Carmichael, M.; Krishnamurthy, T.; Beasley, V.; Yu, M.J.; Bunner, D.L.; Moore, R.E.; Eloff, J.N.; Rinehart, K.; Falconer, I.; Runnegar, M.; et al. Naming of cyclic heptapeptide toxins of cyanobacteria (blue-green algae). Toxicon 1988, 26, 971-973. [CrossRef]

5. Ohtani, I.; Moore, R.E.; Runnegar, M.T.C. Cylindrospermopsin: A potent hepatotoxin from the blue-green alga Cylindrospermopsis raciborskii. J. Am. Chem. Soc. 1992, 114, 7942-7944. [CrossRef]

6. Schantz, E.J.; Ghazarossian, V.E.; Schnoes, H.K.; Strong, F.M.; Springer, J.P.; Pezzanite, J.O.; Clardy, J. Structure of saxitoxin. J. Am. Chem. Soc. 1975, 97, 1238-1239. [CrossRef] [PubMed]

7. Devlin, J.P.; Edwards, O.E.; Gorham, P.R.; Hunter, M.R.; Pike, R.K.; Stavric, B. Anatoxin-a, a toxic alkaloid from Anabaena flos-aquae NCR-44h. Can. J. Chem. 1977, 55, 1367-1371. [CrossRef]

8. Cox, P.A.; Banack, S.A.; Murch, S.J.; Rasmussen, U.; Tien, G.; Bidigare, R.R.; Metcalf, J.S.; Morrison, L.F.; Codd, G.A.; Bergman, B. Diverse taxa of cyanobacteria produce $\beta-N$-methylamino-L-alanine, a neurotoxic amino acid. Proc. Natl. Acad. Sci. USA 2005, 102, 5074-5078. [CrossRef] [PubMed]

9. Cardellina, J.H.; Marner, F.J.; Moore, R.E. Seaweed dermatitis: Structure of lyngbyatoxin A. Science 1979, 204, 193-195. [CrossRef] [PubMed]

10. Kato, Y.; Scheuer, P.J. Aplysiatoxin and debromoaplysiatoxin, constituents of the marine mollusk Stylocheilus longicauda (Quoy and Gaimard, 1824). J. Am. Chem. Soc. 1974, 96, 2245-2246. [CrossRef] [PubMed]

11. Bourke, A.T.C.; Hawes, R.B.; Neilson, A.; Stallman, N.D. An outbreak of hepato-enteritis (the Palm Island mystery disease) possibly caused by algal intoxication. Toxicon 1983, 21, 45-48. [CrossRef]

12. Hawkins, P.R.; Runnegar, M.T.C.; Jackson, A.R.B.; Falconer, I. Severe hepatotoxicity caused by the tropical cyanobactreium (blue-green alga) Cylindrospermopsis raciborskii (Woloszaynska) Seenaya and Subba Raju isolated from a domestic supply reservoir. Appl. Environ. Microbiol. 1985, 50, 1292-1295. [PubMed]

13. Wormer, L.; Cirés, A.; Carrasco, D.; Quesada, A. Cylindrospermopsin is not degraded by co-occurring natural bacterial communities during a 40-day study. Harmful Algae 2008, 7, 206-213. [CrossRef]

14. Runnegar, M.T.; Kong, S.M.; Zhong, Y.Z.; Lu, S.C. Inhibition of reduced glutathione synthesis by cyanobacterial alkaloid cylindrospermopsin in cultured rat hepatocytes. Biochem. Pharmacol. 1995, 49, 219-225. [CrossRef]

15. Froscio, S.M.; Humpage, A.R.; Burcham, P.C.; Falconer, I.R. Cylindrospermopsin-induced protein synthesis inhibition and its dissociation from acute toxicity in mouse hepatocytes. Environ. Toxicol. 2003, 18, $243-251$. [CrossRef] [PubMed]

16. Terao, K.; Ohmori, S.; Igarashi, K.; Ohtani, I.; Watanabe, M.F.; Harada, K.I.; Ito, E.; Watanabe, M. Electron microscopic studies on experimental poisoning in mice induced by cylindrospermopsin isolated from blue-green alga Umezakia natans. Toxicon 1994, 32, 833-843. [CrossRef] 
17. Banker, R.; Carmeli, S.; Werman, M.; Teltsch, B.; Porat, R.; Sukenik, A. Uracil moiety is required for toxicity of the cyanobacterial hepatotoxin cylindrospermopsin. J. Toxicol. Environ. Health A 2001, 62, 281-288. [CrossRef] [PubMed]

18. Li, R.; Carmichael, W.W.; Brittain, S.; Eagalesham, G.K.; Shaw, G.R.; Mahakhant, A.; Noparatnarorn, N.; Yongmanitchai, W.; Kaya, K.; Watamabe, M.M. Isolation and identification of the cyanotoxin cylindrospermopsin and deoxy-cylindrosermopsin from a Thailand strain of Cylindrospermopsis raciborskii (Cyanobacteia). Toxicon 2001, 39, 937-980. [CrossRef]

19. Seifert, M.; McGregor, G.; Eaglesham, G.; Wickramasinghe, W.; Shaw, G. First evidence for the production of cylindrospermopsin and deoxy-cylindrospermopsin by the freshwater benthic cyanobacterium Lyngbya wollei (Farlow ex Gomont) Speziale and Dyck. Harmful Algae 2007, 6, 73-80. [CrossRef]

20. Mihali, T.K.; Kellmann, R.; Muenchhoff, J.; Barrow, K.D.; Neilan, B.A. Characterization of the gene cluster responsible for cylindrospermopsin biosynthesis. Appl. Environ. Microbiol. 2008, 74, 716-722. [CrossRef] [PubMed]

21. Nixdorf, B.; Mischke, U.; Rücker, J. Phytoplankton assemblages and steady state in deep and shallow eutrophic lakes-An approach to differentiate the habitat properties of Oscillatoriales. Hydrobiology 2003, 502, 111-121. [CrossRef]

22. Paerl, H.W.; Hall, N.S.; Calandrino, E.S. Controlling harmful cyanobacterial blooms in a world experiencing anthropogenic and climatic-induced change. Sci. Total Environ. 2011, 409, 1739-1745. [CrossRef] [PubMed]

23. Figueredo, C.C.; Giani, A. Phytoplankton community in the tropical lake of Lagoa Santa (Brazil): Conditions favoring a persistent bloom of Cylindrospermopsis raciborskii. Limnologica 2009, 39, 264-272. [CrossRef]

24. Vidal, L.; Kruk, C. Cylindrospermopsis raciborskii (Cyanobacteria) extends its distribution to Latitude $34^{\circ} 53^{\prime}$ S: Taxonomical and ecological features in Uruguayan eutrophic lakes. Pan-Am. J. Aquat. Sci. 2008, 3, 142-151.

25. Everson, S.; Fabbro, L.; Kinner, S.; Wright, P. Extreme differences in akinete, heterocyte and cylindrospermopsin concentrations with depth in a successive bloom involving Aphanizomenon ovalisporum (Forti) and Cylindrospermopsis raciborskii (Woloszynska) Seenaya and Subba Raju. Harmful Algae 2011, 10, 265-276. [CrossRef]

26. Stüken, A.; Rucker, J.; Endrulat, T.; Preussel, K.; Hemm, M.; Nixdorf, B.; Karsten, U.; Wiedner, C. Distribution of three alien cyanobacterial species (Nostocales) in northeast Germany: Cylindrospermopsis raciborskii, Anabaena bergii and Aphanizomenon aphanizomenoides. Phycologia 2006, 45, 696-703. [CrossRef]

27. Rzymski, P.; Poniedziałek, B. In search of environmental role of cylindrospermopsin: A review on global distribution and ecology of its producers. Water Res. 2014, 66, 320-337. [CrossRef] [PubMed]

28. Burford, M.A.; Beardall, J.; Willis, A.; Orr, P.T.; Magalhaes, V.F.; Rangel, L.; Azevedo, S.M.F.O.E.; Neilan, B.A. Understanding the winning strategies used by the toxic cyanobacterium Cylindrospermopsis raciborskii. Harmful Algae 2016, 54, 44-53. [CrossRef]

29. Briand, J.F.; Leboulange, C.; Humbert, J.F.; Bernard, C.; Dufour, P. Cylidrospermopsis raciborskii (Cyanobacteria) invasion at mid-latitudes: Selection, wide physiological tolerance, or global warming? J. Phycol. 2004, 40, 231-238. [CrossRef]

30. Padisák, J. Cylindrospermopsis raciborskii (Woloszynska) Seenaya et Subba Raju, an expanding, highly adaptive cyanobacterium: Worldwide distribution and review of its ecology. Arch. Hydrobiol. 1997, 107, 563-593.

31. Paerl, H.W.; Paul, V.J. Climate change: Links to global expansion of harmful cyanobacteria. Water Res. 2012, 46, 1349-1363. [CrossRef] [PubMed]

32. O'Neil, J.M.; Davis, T.W.; Burford, M.A.; Gobler, C.J. The rise of harmful cyanobacteria blooms: The potential roles of eutrophication and climate change. Harmful Algae 2012, 14, 313-334. [CrossRef]

33. Smith, V.H. Low nitrogen to phosphorus ratios favor dominance by blue-green algae in lake phytoplankton. Science 1983, 221, 669-671. [CrossRef] [PubMed]

34. Valiei, A.I. Producers and processes involved in primary production. In Marine Ecological Processes, 2nd ed.; Springer: New York, NY, USA, 1995; pp. 3-35.

35. Trimbee, A.M.; Prepas, E.E. Evaluation of total phosphorus as a predictor of the relative biomass of blue-green-algae with emphasis on Alberta lakes. Can. J. Fish. Aquat. Sci. 1987, 44, 1337-1342. [CrossRef]

36. Heisler, J.; Glibert, P.M.; Burkholder, J.M.; Anderson, D.M.; Cochlan, W.; Dennison, W.C.; Dortch, Q.; Gobler, C.J.; Heil, C.A.; Lewitus, A.; et al. Eutrophication and harmful algal blooms: A scientific consensus. Harmful Algae 2008, 8, 3-13. [CrossRef] 
37. Zhou, Q.; Zhang, Y.; Lin, D.; Shan, K.; Luo, Y.; Zhao, L.; Tan, Z.; Song, L. The relationships of meteorological factors and nutrient levels with phytoplankton biomass in a shallow eutrophic lake dominated by cyanobacteria, Lake Dianchi from 1991 to 2013. Environ. Sci. Pollut. Res. 2016, 23, 15616-15626. [CrossRef] [PubMed]

38. Chen, Y.; Tang, L.; Chen, L.; Li, J. Spatial and temporal variations of phosphorus in Dianchi Lake. J. Agro-Environ. Sci. 2005, 24, 1145-1151. (In Chinese)

39. Wang, Z.; Shi, S.; Li, S. The constituent distribution of phosphorus and its effects on phytoplankton in Jiulong River estuary in spring. Adm. Tech. Environ. Monit. 2008, 20, 62-65, (In Chinese with English Abstract).

40. Dyhrman, S.T.; Ammerman, J.W.; Van Mooy, B.A.S. Microbes and the marine phosphorus cycle. Oceanography 2007, 20, 110-116. [CrossRef]

41. Harke, M.J.; Berry, D.L.; Ammerman, J.W.; Gobler, C.J. Molecular response of the bloom-forming cyanobacterium, Microcystis aeruginosa, to phosphorus limitation. Microb. Ecol. 2012, 63, 188-198. [CrossRef] [PubMed]

42. Köhler, J.; Hilt, S.; Adrian, R.; Nicklisch, A.; Kozerski, H.P.; Walz, N. Long-term response of a shallow, moderately flushed lake to reduced external phosphorus and nitrogen loading. Freshw. Biol. 2005, 50, 1639-1650. [CrossRef]

43. Willis, A.; Chuang, A.W.; Burford, M.A. Nitrogen fixation by the diazotroph Cylindrospermopsis raciborskii (Cyanophyceae). J. Phycol. 2016, 52, 854-862. [CrossRef] [PubMed]

44. Chislock, M.F.; Sharp, K.L.; Wilson, A.E. Cylindrospermopsis raciborskii dominates under very low and high nitrogen-to-phosphorus ratios. Water Res. 2014, 49, 207-214. [CrossRef] [PubMed]

45. Bar-Yosef, Y.; Sukenik, A.; Hadas, O.; Viner-Mozzini, Y.; Kaplan, A. Enslavement in the water body by toxic Aphanizomenon ovalisporum, inducing alkaline phosphatase in phytoplanktons. Curr. Biol. 2010, 20, 1557-1561. [CrossRef] [PubMed]

46. Chiswell, R.K.; Shaw, G.R.; Eaglesham, G.; Smith, M.J.; Norris, R.L.; Seawright, A.A.; Moore, M.R. Stability of cylindrospermopsin, the toxin from the cyanobacterium Cylindrospermopsis raciborskii: Effect of $\mathrm{pH}$, temperature, and sunlight on decomposition. Environ. Toxicol. 1999, 14, 155-161. [CrossRef]

47. Rücker, J.; Stüken, A.; Nixdorf, B.; Fastner, J.; Chorus, I.; Wiedner, C. Concentrations of particulate and dissolved cylindrospermopsin in 21 Aphanizomenon-dominated temperate lakes. Toxicon 2007, 50, 800-809. [CrossRef] [PubMed]

48. Jiang, Y.; Xiao, P.; Yu, G.; Shao, J.; Liu, D.; Azevedo, S.M.; Li, R. Sporadic distribution and distinctive variations of cylindrospermopsin genes in cyanobacterial strains and environmental samples from Chinese freshwater bodies. Appl. Environ. Microbiol. 2014, 80, 5219-5230. [CrossRef] [PubMed]

49. Hawkins, P.R.; Putt, E.; Falconer, I.; Humpage, A. Phenotypical variation in a toxic strain of the phytoplankter, Cylindrospermopsis raciborskii (Nostocales Cyanophyceae) during batch culture. Environ. Toxicol. 2001, 16, 460-467. [CrossRef] [PubMed]

50. Saker, M.L.; Griffiths, D.J. The effect of temperature on growth and cylindrospermopsin content of seven isolates of Cylindrospermopsis raciborskii (Nostocales, Cyanophyceae) from water bodies in northern Australia. Phycologia 2000, 39, 349-354. [CrossRef]

51. Bormans, M.; Lengronne, M.; Brient, L.; Duval, C. Cylindrospermopsin accumulation and release by the benthic cyanobacterium Oscillatoria sp. PCC 6506 under different light conditions and growth phases. Bull. Environ. Contam. Toxicol. 2014, 92, 243-247. [CrossRef] [PubMed]

52. Dyble, J.; Tester, P.A.; Litaker, R.W. Effects of light intensity on cylindrospermopsin production in the cyanobacterial HAB species Cylindrospermopsis raciborskii. Afr. J. Mar. Sci. 2006, 28, 309-312. [CrossRef]

53. Davis, T.W.; Orr, P.T.; Boyer, G.L.; Burford, M.A. Investigating the production and release of cylindrospermopsin and deoxy-cylindrospermopsin by Cylindrosermopsis raciborskii over a natural growth cycle. Harmful Algae 2014, 31, 18-25. [CrossRef]

54. Istvánovics, V.; Shafik, H.M.; Présing, M.; Juhos, S. Growth and phosphate uptake kinetics of the cyanobacterium, Cylindrospermopsis raciborskii (Cyanophyceae) in throughflow cultures. Freshw. Biol. 2000, 43, 257-275. [CrossRef]

55. Wu, Z.; Zeng, B.; Li, R.; Song, L. Physiological regulation of Cylindrospermopsis raciborskii (Nostocales, Cyanobacteria) in response to inorganic phosphorus limitation. Harmful Algae 2012, 15, 53-58. [CrossRef] 
56. Amaral, V.; Bonilla, S.; Aubriot, L. Growth optimization of the invasive cyanobacterium Cylindrospermopsis raciborskii in response to phosphate fluctuations. Eur. J. Phycol. 2014, 49, 134-141. [CrossRef]

57. Steffen, M.M.; Dearth, S.P.; Dill, B.D.; Li, Z.; Larsen, K.M.; Campagna, S.R.; Wilhelm, S.W. Nutrients drive transcriptional changes that maintain metabolic homeostasis but alter genome architecture in Microcystis. ISME J. 2014, 8, 2080-2092. [CrossRef] [PubMed]

58. Kenesi, G.; Shafik, H.M.; Kovács, A.W.; Herodek, S.; Présing, M. Effect of nitrogen forms on growth, cell composition and $\mathrm{N}_{2}$ fixation of Cylindrospermopsis raciborskii in phosphorus-limited chemostat cultures. Hydrobiologia 2009, 623, 191-202. [CrossRef]

59. Bonilla, S.; Aubriot, L.; Soares, M.C.S.; González-Piana, M.; Fabre, A.; Huszar, V.L.; Lürling, M.; Antoniades, D.; Padisák, J.; Kruk, C. What drives the distribution of the bloom-forming cyanobacteria Planktothrix agardhii and Cylindrospermopsis raciborskii? FEMS Microbiol. Ecol. 2012, 79, 594-607. [CrossRef] [PubMed]

60. Bácsi, I.; Vasas, G.; Surányi, G.; Mhamvas, M.; Máthé, C.; Tóth, E.; Grigorszky, I.; Gáspár, A.; Tóth, S.; Borbely, G. Alteration of cylindrospermopsin production in sulfate- or phosphate-starved cyanobacterium Aphanizomenon ovalisporum. FEMS Microbiol. Lett. 2006, 259, 303-310. [CrossRef] [PubMed]

61. Mohamed, Z.A.; Al-Shehri, A.M. Assessment of cylindrospermopsin toxin in an arid Saudi lake containing dense cyanobacterial bloom. Environ. Monit. Assess. 2013, 185, 2157-2166. [CrossRef] [PubMed]

62. Burford, M.A.; Davis, T.W.; Orr, P.T.; Sinha, R.; Willis, A.; Neilan, B.A. Nutrient-related changes in the toxicity of field blooms of the cyanobacterium, Cylindrospermopsis raciborskii. FEMS Microbiol. Ecol. 2014, 89, 135-148. [CrossRef] [PubMed]

63. Preußel, K.; Chorus, I.; Fastner, J. Nitrogen limitation promotes accumulation and suppresses release of cylindrospermopsins in cells of Aphanizomenon sp. Toxins 2014, 6, 2932-2947. [CrossRef] [PubMed]

64. Pierangelini, M.; Sinha, R.; Willis, A.; Burford, M.A.; Orr, P.T.; Beardall, J.; Neilan, B.A. Constitutive cylindrospermopsin pool size in Cylindrospermopsis raciborskii under different light and $\mathrm{CO}_{2}$ partial pressure conditions. Appl. Environ. Microbiol. 2015, 81, 3069-3076. [CrossRef] [PubMed]

65. Willis, A.; Adams, M.P.; Chuang, A.W.; Orr, P.T.; O’Brien, K.R.; Burford, M.A. Constitutive toxin production under various nitrogen and phosphorus regimes of three ecotypes of Cylindrospermopsis raciborskii ((Wołoszyńska) Seenayya et Subba Raju). Harmful Algae 2015, 47, 27-34. [CrossRef]

66. Orr, P.T.; Rasmussen, J.P.; Burford, M.A.; Eaglesham, G.K.; Lennox, S.M. Evaluation of quantitative real-time PCR to characterise spatial and temporal variations in cyanobacteria, Cylindrospermopsis raciborskii (Woloszynska) Seenaya et Subba Raju and cylindrospermopsin concentrations in three subtropical Australian reservoirs. Harmful Algae 2010, 9, 243-254. [CrossRef]

67. Stucken, K.; John, U.; Cembella, A.; Soto-Liebe, K.; Vásquez, M. Impact of nitrogen sources on gene expression and toxin production in the diazotroph Cylindrospermopsis raciborskii CS-505 and non-diazotroph Raphidiopsis brookii D9. Toxins 2014, 6, 1896-1915. [CrossRef] [PubMed]

68. Ichimura, T. Isolation and culture methods of algae (Sôrui no bunri to baiyôhô. 2.5.B. Tansui sôrui). In Methods in Phycological Studies (Sôrui Kenkyûhô); Nishizawa, K., Chihara, M., Eds.; Kyoritu Shuppan: Tokyo, Japan, 1979; pp. 294-305. (In Japanese without English Title)

69. Pierangelini, M.; Stojkovic, S.; Orr, P.T.; Beardall, J. Photosynthetic characteristics of two Cylindrospermopsis raciborskii strains differing in their toxicity. J. Phycol. 2014, 50, 292-302. [CrossRef] [PubMed]

70. China Environmental Protection Administration. Water and Wastewater Monitoring and Analysis Methods, 4th ed.; China Environmental Science Press: Beijing, China, 2006; pp. 670-671.

71. Wormer, L.; Carrasco, D.; Cirés, S.; Quesada, A. Advances in solid-phase extraction of the cyanobacterial toxin cylindrospermopsin. Limnol. Oceanogr. Methods 2009, 7, 568-575. [CrossRef]

72. Wu, S.K.; Xie, P.; Liang, G.D.; Wang, S.B.; Liang, X.M. Relationships between microcystins and environmental parameters in 30 subtropical shallow lakes along the Yangtze River, China. Freshw. Biol. 2006, 51, 2309-2319. [CrossRef]

(C) 2016 by the authors; licensee MDPI, Basel, Switzerland. This article is an open access article distributed under the terms and conditions of the Creative Commons Attribution (CC-BY) license (http://creativecommons.org/licenses/by/4.0/). 